\title{
CORRIGENDUM
}

\section{Association of polymorphisms in the mannose-binding lectin gene and pulmonary morbidity in preterm infants}

A Hilgendorff, K Heidinger, A Pfeiffer, A Bohnert, IR König, A Ziegler, C Merz, G Frey, T Chakraborty, L Gortner and G Bein

Genes and Immunity (2008) 9, 481; doi:10.1038/gene.2008.46

Correction to: Genes and Immunity (2007) 8, 671-677; doi:10.1038/sj.gene.6364432

Since publication of this paper, the authors have noticed that Table 1 is incorrect.

Table 1 Patients baseline characteristics

\begin{tabular}{lc}
\hline & $\mathrm{n}=283$ \\
\hline GA (weeks) & $28.7 \pm 2.4$ \\
Gender & 153 male $(54.1 \%)$ \\
Birth weight (gram) & $1177 \pm 404$ \\
ANCS (y/n) & $175(70.3 \%)$ \\
Chorioamnionitis & $99(43.6 \%)$ \\
IUGR & $41(14.5 \%)$ \\
EOI & $107(38.1 \%)$ \\
RDS & $202(74.8 \%)$ \\
RDS grade III & $88(32.8 \%)$ \\
PDA & $99(46.7 \%)$ \\
Surfactant & $137(48.9 \%)$ \\
Mechanical ventilation & $150(60.2 \%)$ \\
Days & $6.0 \pm 13.8$ \\
BPD & $88(31.4 \%)$ \\
Mild & $56(67.5 \%)$ \\
Moderate & $19(22.9 \%)$ \\
Severe & $7(8.4 \%)$ \\
Oxygen supplementation (days) & $22.6 \pm 33.0$ \\
\hline
\end{tabular}

The correct table is displayed below.

The authors would like to apologize for this error. 